\title{
Experimental Study of the Phase Equilibria in the R-Al-Si Ternary Systems (R: Rare Earth Element) the Ho-Al-Si Isothermal Section at $500^{\circ} \mathrm{C}$
}

\author{
Anna Maria Cardinale, Nadia Parodi \\ Dipartimento di Chimica e Chimica Industriale, Università di Genova, Genova, Italy \\ Email: cardinal@chimica.unige.it
}

How to cite this paper: Cardinale, A.M. and Parodi, N. (2019) Experimental Study of the Phase Equilibria in the R-Al-Si Ternary Systems (R: Rare Earth Element) the Ho-Al-Si Isothermal Section at $500^{\circ} \mathrm{C}$. Journal of Materials Science and Chemical Engineering, 7, 9-17.

https://doi.org/10.4236/msce.2019.78002

Received: May 24, 2019

Accepted: August 9, 2019

Published: August 12, 2019

\begin{abstract}
The effect of holmium addition to the Al-Si system has been experimentally studied, as the isothermal section at $500^{\circ} \mathrm{C}$. The constitution of the alloys has been determined by means of scanning electron microscopy (SEM), electron microprobe analysis (EDXS) and X-ray powder diffraction. The knowledge of the phase relationships in the R-Al-Si ternary systems (R: rare earths element) is essential to deeply understand the technological properties of the Al-Si based alloys, that are useful in different industrial fields. In the system investigated have been identify nineteen ternary fields and twelve two phase fields. Three ternary compounds have been found in this ternary section: $\tau_{2}-\mathrm{Ho}_{2} \mathrm{Al}_{3} \mathrm{Si}_{2}$ $\left(\mathrm{mS} 14-\mathrm{Y}_{2} \mathrm{Al}_{3} \mathrm{Si}_{2}\right), \tau_{4}-\mathrm{Ho}_{2} \mathrm{AlSi}_{2}\left(\mathrm{oI} 10-\mathrm{W} 2 \mathrm{CoB}_{2}\right)$ and $\tau_{5}-\mathrm{Ho}_{6} \mathrm{Al}_{3} \mathrm{Si}\left(\mathrm{tI} 80-\mathrm{Tb}_{6} \mathrm{Al}_{3} \mathrm{Si}\right)$. The results obtained can be useful compared with the other known R-Al-Si systems also for predictive purposes.
\end{abstract}

\section{Keywords}

Al-Si Alloys, Rare Earth, Thermal Analysis

\section{Introduction}

The Al-Si alloys, both in the as cast and after thermal treatment conditions, have been recognized as interesting materials for the industries (e.g. automotive, heat exchanger, etc.). The addition of a rare earth element, at a very low concentration, can modify the property of the alloys, improving some useful characters as low density and thermal expansion coefficients, good casting performance and weld ability, high wear resistance and temperature strength, good corrosion re- 
sistance [1] [2] [3] [4]. All of the above leads to an increasing interest in the study of R-Al-Si based alloys ( $\mathrm{R}$ being a trivalent rare earth element). The knowledge of the phase equilibria and the transformations that take place during the solidification pathway of foundry aluminum based alloys are crucial, especially in planning and develop new materials. The industrially relevant R-Al-Si alloys have usually a concentration lying near the binary Al-Si eutectic composition and mischmetal (alloy of rare earth metals, whose typical composition includes approximately $50 \% \mathrm{Ce}, 25 \% \mathrm{La}$ and smaller small amounts of $\mathrm{Nd}$ and $\mathrm{Pr}$ ) is often added.

Moreover, owing to the definition of pseudo-lanthanide [5] it is possible to predict the behavior of an intermetallic phase not prepared yet, when experimental data are available for the adjacent members of this series. Taking into account the aforementioned considerations, investigations of a number of R-Al-Si systems have been carried out by our research group.

\section{Literature Data}

\subsection{Boundary Binary Systems}

As far as the binary systems are concerned, the Al-Si phase diagram is a simple eutectic, with the eutectic reaction at 12.2 at $\% \mathrm{Si}$ and $577^{\circ} \mathrm{C}$ and with no intermetallic compounds found in this system [6]. Phase relationships in the Ho-Al system were assessed by [7]. There are five intermetallic compounds: $\mathrm{Ho}_{2} \mathrm{Al}$ (oP12- $\mathrm{Co}_{2} \mathrm{Si}$ type), $\mathrm{Ho}_{3} \mathrm{Al}_{2}$ ( $\mathrm{tP} 20-\mathrm{Al}_{2} \mathrm{Zr}_{3}$ type), $\mathrm{HoAl}$ (oP16-ErAltype), $\mathrm{HoAl}_{2}$ (cF24- $\mathrm{MgCu}_{2}$ type) and $\mathrm{HoAl}_{3}\left(\mathrm{hR} 60-\mathrm{Al}_{3} \mathrm{Ho}\right.$ ). The Ho-Si system, was recently assessed by [8]; at $500^{\circ} \mathrm{C}$ temperature there are six intermetallic compounds in it as well: $\mathrm{Ho}_{5} \mathrm{Si}_{3}\left(\mathrm{hP} 16-\mathrm{Mn}_{5} \mathrm{Si}_{3}\right.$ type), $\mathrm{Ho}_{5} \mathrm{Si}_{4}$ (oP36-Sm $\mathrm{Se}_{4}$ type), $\mathrm{HoSi}$ (oP8-FeB type), $\mathrm{Ho}_{4} \mathrm{Si}_{5}, \mathrm{HoSi}_{2-\mathrm{b}}$ (hP3- $\mathrm{AlB}_{2}$ type, $\sim 38$ at $\% \mathrm{Ho}$ ) and $\mathrm{HoSi}_{2-\mathrm{a}}$ (oI12-GdSi $i_{2}$ type, $\sim 35$ at $\% \mathrm{Ho}$ ). The $\mathrm{Ho}_{4} \mathrm{Si}_{5}$ compound was investigated [9] by means of single crystal $\mathrm{X}$-ray diffraction and its structure was assumed to be $\mathrm{Ho}_{3} \mathrm{Si}_{4} \mathrm{OS} 24-\mathrm{Ho}_{2} \mathrm{Si}_{2.67}$ type.

\subsection{R-Al-Si Ternary Systems}

To our best effort literature data on R-Al-Si systems isothermal sections (in the whole range of concentrations) and liquid us projections mainly deal with the following: La-Al-Si (0 - 33 at \% La) [10], Ce-Al-Si [11], Pr-Al-Si [12] [13], Nd-Al-Si [13], Sm-Al-Si ([13] and refs therein [14]), Eu-Al-Si [15], Gd-Al-Si, $\mathrm{Al}-\mathrm{Si}-\mathrm{Tb}$ and Al-Si-Dy ([13] and refs therein), Ho-Al-Si (0 - 33 at \% Ho) [16], Er-Al-Si [17] and Y-Al-Si (0 - 33 at \% Y) [18]. In the Ho-Al-Si ternary system, in literature [19], are reported the following compounds: $\mathrm{HoAl}_{2} \mathrm{Si}_{2} \mathrm{hP5}-\mathrm{CaAl}_{2} \mathrm{O}_{2}\left(\tau_{1}\right)$, $\mathrm{Ho}_{2} \mathrm{Al}_{3} \mathrm{Si}_{2}$ mS14- $\mathrm{Y}_{2} \mathrm{Al}_{3} \mathrm{Si}_{2}\left(\tau_{2}\right)$, HoAlSi oS12-YAlGe $\left(\tau_{3}\right), \mathrm{Ho}_{2} \mathrm{Al}_{1+\mathrm{x}} \mathrm{Si}_{2-\mathrm{x}}$ oI10-W $\mathrm{CoB}_{2}$ $\left(\tau_{4}\right)$ and $\mathrm{Ho}_{6} \mathrm{Al}_{3} \mathrm{Si} \mathrm{tI80-}-\mathrm{Tb}_{6} \mathrm{Al}_{3} \mathrm{Si}\left(\tau_{5}\right)$.

\section{Experimental Techniques}

A set of eighteen Ho-Al-Si alloys have been prepared starting from pure ele- 
ments (aluminum, silicon and holmium at 99.999, 99.99 and 99.9 mass \% purity respectively all supplied by Newmet Koch, Waltham Abbey, England). The starting metals, prepared in little pieces, have been weighed in a proper amount and then arc melted on a water cooled copper plate under vacuum, the samples were re-weighed after melting to check for any mass losses that were always less than 0.5 mass \%. The samples have been annealed (in an alumina crucibles sealed in quartz tube under vacuum) at $500^{\circ} \mathrm{C}$ for 720 hours and then quenched in water.

To characterize the samples after annealing the techniques used have been scanning electron microscopy (SEM), electron probe microanalysis based on energy dispersive X-ray spectroscopy (EDXS) and X-ray diffraction analysis (XRPD). As the metallographic analysis, the samples incorporated in a conductive resin support were prepared according to the standard method by $\mathrm{SiC}$ paper and diamond paste polishing. After preparation the samples have been analyzed applying an acceleration voltage of $20 \mathrm{kV}$ for $50 \mathrm{~s}$, and a cobalt standard was used for calibration. For the quantitative analysis the software packaging Inca Energy (Oxford Instruments, Analytical Ltd., Bucks, UK) was employed to process X-ray spectra.

To determine the crystal structures, and calculate lattice parameters of the different phases, the samples were prepared crushing them into powder in an agate mortar; then XRPD analysis was performed by the vertical diffractometer X'Pert MPD (Philips, Almelo, and The Netherlands). The indexing of the obtained diffraction data was achieved by comparison with literature or calculated data (the program Powder Cell [20]), the lattice parameters of the phases were calculated using the program LATCON [21].

\section{Results and Discussion}

Table 1 reports data obtained from the eighteen samples synthesized and characterized by using SEM/EDXS and X-ray powder diffraction, while Figure 1 reports the $\mathrm{Ho}-\mathrm{Al}-\mathrm{Si}$ isothermal section at $500^{\circ} \mathrm{C}$. It was drawn basing on the experimental data in Table 1 and contains the samples composition, the field described by means of dotted lines are hypothesized on the basis of the experimental data and the knowledge of the different R-Al-Si systems. In Figure 2 are shown the micrographic appearance of some selected samples after annealing and quenching, while Figure 3 reports the PXRD pattern of a three phase sample.

\subsection{Ternary Isothermal Section}

In the present work the system is characterized by nineteen three-phase fields and twelve two-phase fields. According with the previous study of the Ho-Al-Si system [16], the $\mathrm{HoAl}_{2} \mathrm{Si}_{2}\left(\tau_{1}\right)$ compound was not found in the isothermal section at $500^{\circ} \mathrm{C}$, this is an unusual behavior when compared with all the other known R-Al-Si systems all showing the tie triangle (Al), $(\mathrm{Si})$ and $\tau_{1}$. Furthermore, in the Er-Al-Si isothermal section at $600^{\circ} \mathrm{C}$ [17] the $\mathrm{ErAl}_{2} \mathrm{Si}_{2}$ phase was not 


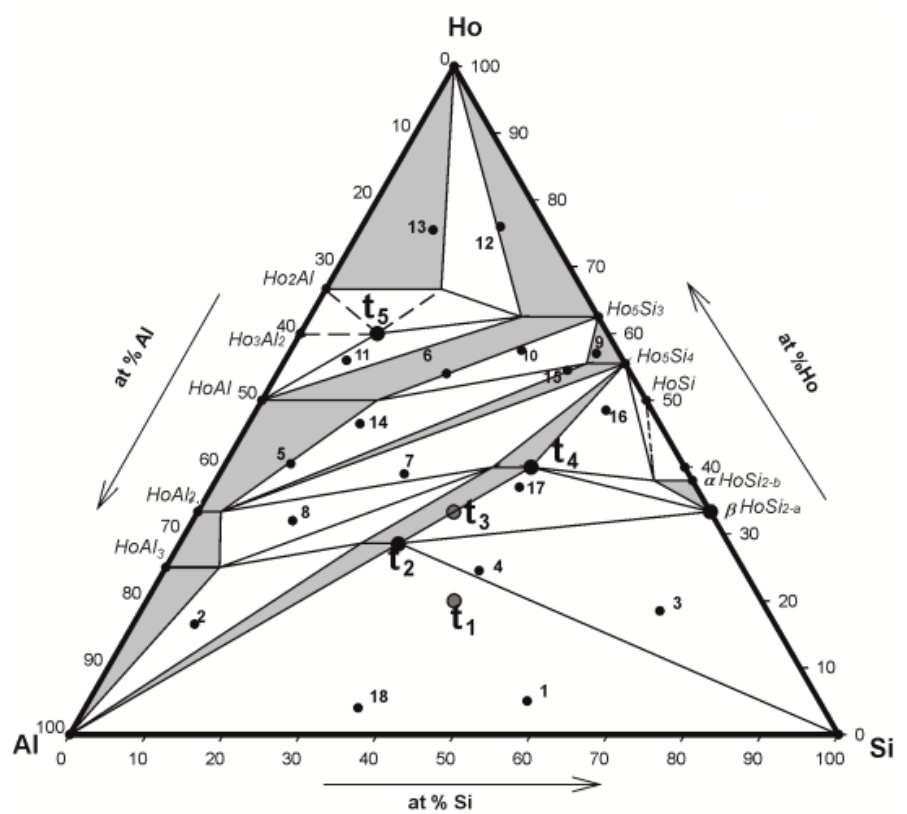

Figure 1. The Ho-Al-Si ternary isothermal section at $500^{\circ} \mathrm{C}$, position and code of the samples are superimposed.

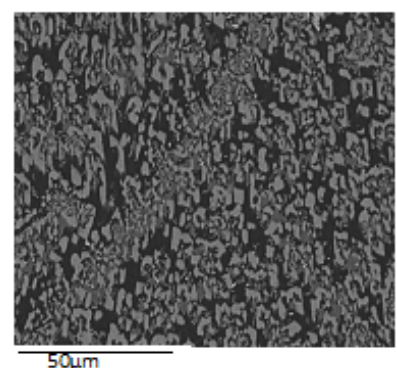

(a)

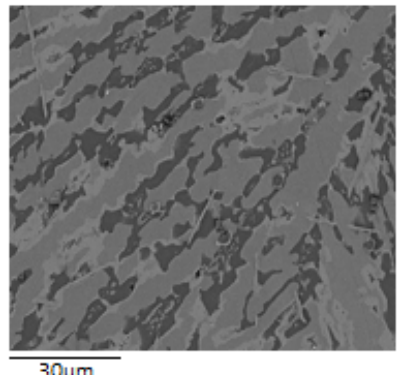

(c)

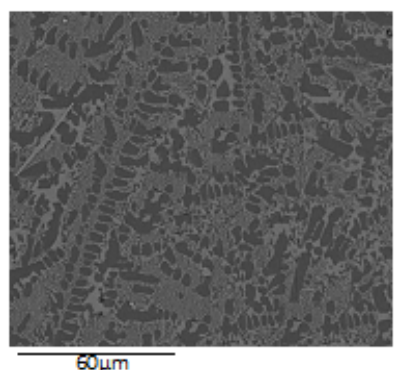

(b)

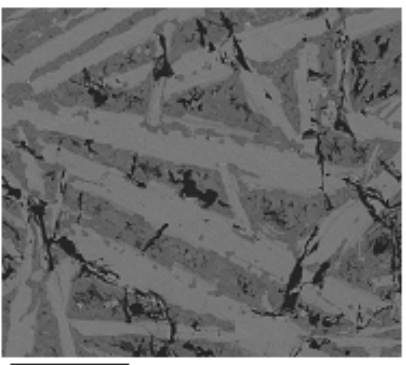

(d)

Figure 2. Back scattered electrons (BSE) images of some selected Ho-Al-Si samples after annealing and quenching, the composition is reported in Table 1: (a) Sample n.8, primary light $\mathrm{Ho}_{2} \mathrm{Al}_{\mathrm{x}} \mathrm{Si}_{(2-\mathrm{x})}\left(\tau_{4}\right)$, surrounded by small quantity of grey $\mathrm{HoAl}_{(2-\mathrm{x})} \mathrm{Si}_{\mathrm{x}}$ phase plus black $\mathrm{HoAl}_{(3-\mathrm{x})} \mathrm{Si}_{\mathrm{x}}$ compound; (b) Sample n.5, two phase sample constituted by primary dark $\operatorname{HoAl}_{(2-\mathrm{x})} \mathrm{Si}_{\mathrm{x}}$ phase plus light $\mathrm{HoAl}_{(1-\mathrm{x})} \mathrm{Si}_{\mathrm{x}}$ compound; (c) Sample n.14, primary gray $\mathrm{HoAl}_{(1-\mathrm{x})} \mathrm{Si}_{\mathrm{x}}$ crystals surrounded by small quantity of light peritectic $\mathrm{Ho}_{5} \mathrm{Al}_{\mathrm{x}} \mathrm{Si}_{(4-\mathrm{x})}$ compound plus the black $\mathrm{HoAl}_{(2-\mathrm{x})} \mathrm{Si}_{\mathrm{x}}$ phase; (d) Sample n.16 primary light polygonal crystal of $\mathrm{Ho}_{5} \mathrm{Si}_{4}$ compound surrounded by peritectic formed $\mathrm{Ho}_{2} \mathrm{AlSi}_{2}\left(\tau_{4}\right)$ and $\mathrm{HoAlSi}_{(2-\mathrm{b})}$ containing 6 at $\% \mathrm{Al}$. 
Table 1. SEM-EDX and XRPD data on the Ho-Al-Si samples annealed at $500^{\circ} \mathrm{C}$ and quenched.

\begin{tabular}{|c|c|c|c|c|c|c|c|}
\hline \multirow{2}{*}{ N. } & \multirow{2}{*}{$\begin{array}{c}\text { Nominal } \\
\text { composition } \\
\text { Ho, } \mathrm{Al}, \mathrm{Si} / \text { at } \%\end{array}$} & \multirow{2}{*}{$\begin{array}{c}\text { Phases } \\
\text { crystal structure }\end{array}$} & \multirow{2}{*}{$\begin{array}{c}\text { EDXS results } \\
\mathrm{Ho}, \mathrm{Al}, \mathrm{Si} / \text { at } \%\end{array}$} & \multicolumn{4}{|c|}{ Lattice parameters/nm } \\
\hline & & & & a & b & c & $\beta l^{\circ}$ \\
\hline \multirow{3}{*}{1} & \multirow{3}{*}{$5.0,38.0,57.0$} & Si $c F 8-C_{\text {diam }}$ & $0.0,0.0,100.0$ & $0.5428(1)$ & & & \\
\hline & & $\mathrm{Al} c F 4-C u$ & $0.0,100.0,0.0$ & $0.4045(1)$ & & & \\
\hline & & $\tau_{2} m S 14-Y_{2} \mathrm{Al}_{3} S i_{2}$ & $29.0,45.0,26.0$ & $1.0083(2)$ & $0.4013(1)$ & $0.6560(8)$ & 100.82 \\
\hline \multirow{3}{*}{2} & \multirow{3}{*}{$16.5,75.5,8.0$} & $\mathrm{Al} c F 4-C u$ & $0.0,100.0,0.0$ & $0.4047(1)$ & & & \\
\hline & & $\tau_{2} m S 14-Y_{2} A_{3} S i_{2}$ & $30.0,45.5,24.5$ & $1.0091(9)$ & $0.4015(5)$ & $0.6572(9)$ & 100.78 \\
\hline & & $\mathrm{HoAl}_{3-\mathrm{x}} \mathrm{Si}_{\mathrm{x}} h R 60-\mathrm{HoAl}_{3}$ & $26.0,67.0,7.0$ & $0.6100(1)$ & $0.6100(1)$ & $3.4961(9)$ & \\
\hline \multirow{3}{*}{3} & \multirow{3}{*}{$18.5,14.0,67.5$} & Si $c F 8-C_{\text {diam }}$ & $0.0,0.0,100.0$ & $0.5426(3)$ & & & \\
\hline & & $\tau_{2} m S 14-Y_{2} A I_{3} S i_{2}$ & $29.5,44.0,26.5$ & $1.0093(5)$ & $0.4012(1)$ & $0.6563(1)$ & 100.82 \\
\hline & & $\mathrm{HoSi}_{2-\mathrm{a}} o I 12-G d S i_{2}$ & $36.0,0.0,64.0$ & $0.3915(2)$ & $0.4015(1)$ & $1.3371(9)$ & \\
\hline \multirow{2}{*}{4} & \multirow{2}{*}{$25.0,34.0,41.0$} & Si $c F 8-C_{\text {diam }}$ & $0.0,0.0,100.0$ & $0.5424(4)$ & & & \\
\hline & & $\tau_{2} m S 14-Y_{2} A I_{3} S i_{2}$ & $31.0,43.0,26.0$ & $1.0090(7)$ & $0.4011(3)$ & $0.6561(5)$ & 100.94 \\
\hline \multirow{2}{*}{5} & \multirow{2}{*}{$40.5,51.0,8.5$} & Ho $\mathrm{Al}_{(2-\mathrm{x})} \mathrm{Si}_{\mathrm{x}} c F 24-M g C u_{2}$ & $33.0,64.0,3.0$ & $0.7825(2)$ & & & \\
\hline & & $\mathrm{HoAl}_{1-\mathrm{x}} \mathrm{Si}_{\mathrm{x}} o P 16-A l E r$ & $48.0,40.0,12.0$ & $0.5900(2)$ & $1.1401(9)$ & $0.5578(3)$ & \\
\hline \multirow{2}{*}{6} & \multirow{2}{*}{$54.0,24.0,22.0$} & $\mathrm{Ho}_{5} \mathrm{Si}_{3} h P 16-M n_{5} S i_{3}$ & $66.5,0.0,33.5$ & $0.8371(9)$ & $0.8371(9)$ & $0.6276(9)$ & \\
\hline & & $\mathrm{HoAl}_{1-\mathrm{x}} \mathrm{Si}_{\mathrm{x}} o P 16-A l E r$ & $52.0,33.0,15.0$ & $0.5739(4)$ & $1.1250(5)$ & $0.5691(8)$ & \\
\hline \multirow{3}{*}{7} & \multirow{3}{*}{$39.0,37.0,24.0$} & $\mathrm{Ho}_{5} \mathrm{Si}_{4} o P 36-\mathrm{Ge}_{4} S_{5}$ & $56.0,0.0,44.0$ & $0.7335(4)$ & $1.4406(5)$ & $0.7614(2)$ & \\
\hline & & $\mathrm{HoAl}_{2-\mathrm{x}} \mathrm{Si}_{\mathrm{x}} c F 24-M g C u_{2}$ & $33.0,64.5,2.5$ & $0.7800(3)$ & & & \\
\hline & & $\tau_{4} o I 10 W_{2} \mathrm{CoB}_{2}$ & $43.0,25.0,32.0$ & $0.4005(1)$ & $0.5903(3)$ & $0.8528(1)$ & \\
\hline \multirow{3}{*}{8} & \multirow{3}{*}{$32.0,55.0,13.0$} & $\tau_{4} \mathrm{oIIO} \mathrm{W}_{2} \mathrm{CoB}_{2}$ & $42.5,26.0,31.5$ & $0.4143(6)$ & $0.5712(4)$ & $0.8519(4)$ & \\
\hline & & $\mathrm{HoAl}_{2-\mathrm{x}} \mathrm{Si}_{\mathrm{x}} c F 24-M g C u_{2}$ & $34.0,63.0,3.0$ & $0.7796(3)$ & & & \\
\hline & & $\mathrm{HoAl}_{3-\mathrm{x}} \mathrm{Si}_{\mathrm{x}} h R 60-\mathrm{HoAl}_{3}$ & $26.5,68.5,5.0$ & $0.6011(6)$ & $0.6011(6)$ & $3.5550(5)$ & \\
\hline 0 & 57020400 & $\mathrm{Ho}_{5} \mathrm{Si}_{3} h P 16-M n_{5} S i_{3}$ & $67.5,0.0,32.5$ & $0.8341(2)$ & $0.8341(2)$ & $0.6215(5)$ & \\
\hline 9 & $37.0,3.0,40.0$ & $\mathrm{Ho}_{5} \mathrm{Al}_{\mathrm{x}} \mathrm{Si}_{(4-\mathrm{x})} o P 36-G e_{4} S m_{5}$ & $55.0,4.0,41.0$ & $0.7315(6)$ & $1.4429(6)$ & $0.7610(2)$ & \\
\hline & & $\mathrm{Ho}_{5} \mathrm{Si}_{3} h P 16-M n_{5} S_{3}$ & $65.0,0.0,35.0$ & $0.8329(3)$ & $0.8329(3)$ & $0.6217(5)$ & \\
\hline 10 & $57.5,12.5,30.0$ & $\mathrm{Ho}_{5} \mathrm{Si}_{(4-\mathrm{x})} \mathrm{Al}_{\mathrm{x}} o P 36-G e_{4} S m_{5}$ & $53.5,6.0,40.5$ & $0.7321(5)$ & $1.4439(1)$ & $0.7616(9)$ & \\
\hline & & $\mathrm{HoAl}_{1-\mathrm{x}} \mathrm{Si}_{\mathrm{x}}$ oP16-AIEr & $45.0,41.0,14.0$ & $0.5752(4)$ & $1.1167(2)$ & $0.5579(6)$ & \\
\hline & & $\mathrm{Ho}_{5} \mathrm{Al}_{\mathrm{x}} \mathrm{Si}_{3-\mathrm{x}} h P 16-M n_{5} S i_{3}$ & $65.5,11.5,23.0$ & $0.8354(2)$ & $0.8354(2)$ & $0.6262(5)$ & \\
\hline 11 & $56.0,36.0,8.0$ & HoAloP16-AlEr & $50.0,50.0,0.0$ & $0.5803(9)$ & $1.1288(8)$ & $0.5584(6)$ & \\
\hline & & $\tau_{5} t I 80-T b_{6} A l_{3} S i$ & $55.0,35.0,10.0$ & $1.1392(3)$ & $1.1392(3)$ & $1.4981(2)$ & \\
\hline 12 & 76060.180 & $\mathrm{Ho}_{5} \mathrm{Al}_{\mathrm{x}} \mathrm{Si}_{3-\mathrm{x}} h P 16-\mathrm{Mn}_{5} S i_{3}$ & $67.5,8.0,26.5$ & $0.8355(3)$ & $0.8355(3)$ & $0.6266(5)$ & \\
\hline 12 & $76.0,6.0,18.0$ & (Ho) $h P 2-M g$ & $100.0,0.0,0.0$ & $0.3618(5)$ & $0.3618(5)$ & $0.5650(3)$ & \\
\hline 12 & 75515005 & (Нo) $h P 2-M g$ & $100.0,0.0,0.0$ & $0.3614(4)$ & $0.3614(4)$ & $0.5644(7)$ & \\
\hline 13 & $75.5,15.0,9.5$ & $\mathrm{Ho}_{2} \mathrm{Al}_{(1-\mathrm{x})} \mathrm{Si}_{\mathrm{x}} o P 12-\mathrm{Co}_{2} S i$ & $66.5,19.0,14.5$ & $0.6537(2)$ & $0.5052(1)$ & $0.9330(2)$ & \\
\hline & & $\mathrm{HoAl}_{1-\mathrm{X}} \mathrm{Si}_{\mathrm{x}} o P 16-A l E r$ & $52.5,15.0,32.5$ & $0.5801(5)$ & $1.1342(2)$ & $0.5641(4)$ & \\
\hline 14 & $46.5,39.0,14.5$ & $\mathrm{Ho}_{5} \mathrm{Al}_{\mathrm{x}} \mathrm{Si}_{(4-\mathrm{x})} o P 36-\mathrm{Ge}_{4} \mathrm{Sm}_{5}$ & $55.0,36.5,8.5$ & $0.7336(9)$ & $1.4419(8)$ & $0.7597(8)$ & \\
\hline & & $\mathrm{HoAl}_{(2-\mathrm{x})} \mathrm{Si}_{\mathrm{x}} c F 24-M g C u_{2}$ & $36.5,60.5,3.0$ & $0.7815(1)$ & & & \\
\hline 15 & $54.5,8.5,37.5$ & $\mathrm{Ho}_{5} \mathrm{Al}_{\mathrm{x}} \mathrm{Si}_{(4-\mathrm{x})} o P 36-G e_{4} S m_{5}$ & $55.0,4.0,41.0$ & $0.7310(9)$ & $1.4450(9)$ & $0.7643(7)$ & \\
\hline & & $\mathrm{Ho}_{5} \mathrm{Si}_{4} o P 36-\mathrm{Ge}_{4} \mathrm{Sm}_{5}$ & $55.0,0.0,45.0$ & $0.7338(7)$ & $1.4403(9)$ & $0.7611(9)$ & \\
\hline 16 & $48.5,8.5,45.5$ & $\tau_{4} \mathrm{oIIO}-\mathrm{W}_{2} \mathrm{CoB}_{2}$ & $42.5,19.0,38.5$ & $0.4022(4)$ & $0.5739(3)$ & $0.8583(6)$ & \\
\hline & & $\mathrm{HoSi}_{2-\mathrm{b}} h P 3-A l B_{2}$ & $38.0,6.0,56.0$ & $0.3804(1)$ & $0.3804(1)$ & $0.4098(2)$ & \\
\hline & & $\tau_{4} . o I 10-W_{2} \mathrm{CoB}_{2}$ & $41.0,18.0,41.0$ & $0.4017(2)$ & $0.5740(2)$ & $0.8577(2)$ & \\
\hline 17 & $37.0,23.0,40.0$ & $\tau_{2} m S 14-Y_{2} \mathrm{Al}_{3} \mathrm{Si}_{2}$ & $29.0,44.0,27.0$ & $1.0112(8)$ & $0.4019(3)$ & $0.6564(7)$ & 100.98 \\
\hline & & $\mathrm{HoSi}_{2-\mathrm{a}} o I 12-G d S i_{2}$ & $36.0,0.0,64.0$ & $0.3929(4)$ & $0.4019(2)$ & $1.3348(8)$ & \\
\hline & & Si $c F 8-C_{\text {diam }}$ & $0.0,0.0,100.0$ & $0.5427(2)$ & & & \\
\hline 18 & $4.0,60.5,35.5$ & $\mathrm{Al} c F 4-C u$ & $0.0,100.0,0.0$ & $0.4046(1)$ & & & \\
\hline & & $\tau_{2} m S 14-Y_{2} A_{3} S i_{2}$ & $29.5,44.0,26.5$ & $1.0083(5)$ & $0.4013(2)$ & $0.6560(4)$ & 100.81 \\
\hline
\end{tabular}




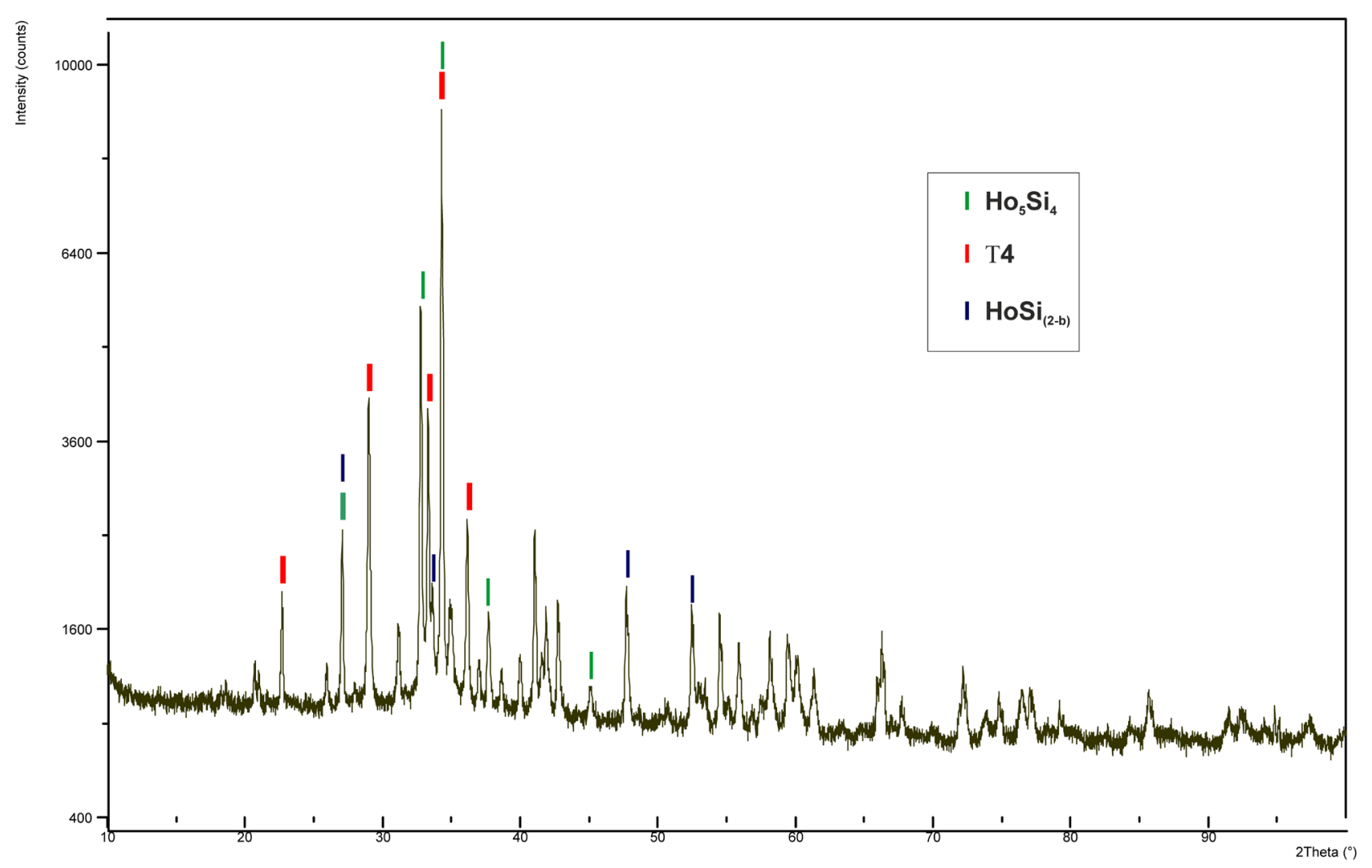

Figure 3. X-ray powder pattern of sample n.16 (see Table 1).

found and the tie triangle in the $\mathrm{Al}$ and $\mathrm{Si}$ rich part of the system shows the same vertices as the Ho-Al-Si system. The micrographs of four representative samples are reported in Figure 2. Figure 2(a)) shows the appearance of the sample n.8 that describes the triangle constituted by the two phases $\operatorname{HoAl}_{(2-\mathrm{x})} \mathrm{Si}_{\mathrm{x}}$ and $\mathrm{HoAl}_{(3-\mathrm{x})} \mathrm{Si}_{\mathrm{x}}$ (respectively grey and black and both at their maximum silicon solubility), plus light $\mathrm{Ho}_{2} \mathrm{Al}_{\mathrm{x}} \mathrm{Si}_{(2-\mathrm{x})}\left(\tau_{4}\right)$ at its maximum aluminum solubility value. In Figure 2(b), the sample n.5, pertaining to the two $\operatorname{HoAl}_{(2-x)} S_{\mathrm{x}}$ and $\operatorname{HoAl}_{(1-\mathrm{x})} \mathrm{Si}_{\mathrm{x}}$ phase field, shows dark primary $\mathrm{HoAl}_{(2-\mathrm{x})} \mathrm{Si}_{\mathrm{x}}$ crystals and the binary eutectic between the primary phase and $\operatorname{HoAl}_{(1-\mathrm{x})} \mathrm{Si}_{\mathrm{x}}$ compound, the medium eutectic composition is $\mathrm{Ho} 42$ at \% and $\mathrm{Al} 46$ at \% very close to the composition of the sample as confirmed by the micrographic feature. Ongoing throughout the system to the Ho richest part, in Figure 2(c) the sample n.14 is a three phase sample with gray primary $\mathrm{HoAl}_{(1-\mathrm{x})} \mathrm{Si}_{\mathrm{x}}$ compound (at its maximum silicon solubility) surrounded by a small quantity of light $\mathrm{Ho}_{5} \mathrm{Al}_{x} \mathrm{Si}_{(4-x)}$ of peritectic formation, plus black $\mathrm{HoAl}_{(2-\mathrm{x})} \mathrm{Si}_{\mathrm{x}}$ phase. The sample n.16, in Figure 2(d) belongs to the $\mathrm{Ho}_{2} \mathrm{Al}_{\mathrm{x}} \mathrm{Si}_{(2-\mathrm{x})}$ $\left(\tau_{4}\right), \mathrm{Ho}_{5} \mathrm{Si}_{4}$ and $\mathrm{HoSi}_{2-\mathrm{b}}$ tietriangle; the PXRD pattern of sample n.16 is reported in Figure 3, the main reflections of the three phases identify are highlighted.

\subsection{Ternary Compounds}

Five ternary intermetallic compounds, are reported in literature: $\tau_{1}$ - $\mathrm{HoAl}_{2} \mathrm{Si}_{2}$ (hP5-CaAl $\left.\mathrm{Si}_{2}\right), \tau_{2}-\mathrm{Ho}_{2} \mathrm{Al}_{3} \mathrm{Si}_{2}\left(\mathrm{mS14}-\mathrm{Y}_{2} \mathrm{Al}_{3} \mathrm{Si}_{2}\right), \tau_{3}$-HoAlSi (oS12-YAlGe), $\tau_{4}-\mathrm{Ho}_{2} \mathrm{AlSi}_{2}$ 
$\left(\mathrm{oI} 10-\mathrm{W} 2 \mathrm{CoB}_{2}\right)$ and $\tau_{5}-\mathrm{Ho}_{6} \mathrm{Al}_{3} \mathrm{Si}\left(\mathrm{tI} 80-\mathrm{Tb}_{6} \mathrm{Al}_{3} \mathrm{Si}\right)$. In this work only three compounds were identified at $500^{\circ} \mathrm{C}$; the $\tau_{3}$ structure seems not to form in the system at $500^{\circ} \mathrm{C}$ and the $\tau_{1}$ phase was not found in the system as discussed in the previous section. The $\tau_{2}$ compound shows a homogeneity range with constant Ho content, dissolving up to 45 at \% Al (stoichiometric composition is located at 42.8 at $\% \mathrm{Al}$ ). As the $\tau_{4}$ compound has been proved the substitution with $\mathrm{Al}$ for $\mathrm{Si}$ in a range from 20.0 at \% $\mathrm{Al}$ (stoichiometric composition) to 25 at $\% \mathrm{Al}$.

\subsection{Binary Compounds}

As expected different boundary binary compounds entry the ternary system, the homogeneity ranges minor of 2 at \% are not taking into account. For each compound involved the solubility limit of the third element has been assumed as the medium value of the different experimental measurements in the different samples investigated. From the $\mathrm{Ho}-\mathrm{Al}$ system, the $\mathrm{HoAl}_{3}, \mathrm{HoAl}_{2}$ and $\mathrm{HoAl}$ compounds dissolve respectively 7 at \%, 3 at \% and 15 at \% silicon. Ongoing from the Si to the Ho richest part of the binary Ho-Si phase diagram some compounds dissolve aluminium in the following percentage: $\mathrm{HoSi}_{2-\mathrm{b}} 4$ at $\%, \mathrm{Ho}_{5} \mathrm{Si}_{4} 5$ at $\%$ and $\mathrm{Ho}_{5} \mathrm{Si}_{3} 10$ at \%.

\section{Conclusions}

The Ho-Al-Si-isothermal section at $500^{\circ} \mathrm{C}$ has been studied in the whole composition range, as the phase relationships the main conclusions are the following:

- The studied system consists of nineteen three-phase fields and twelve two-phase fields.

- Of the five known ternary compounds only $\tau_{2}-\mathrm{Ho}_{2} \mathrm{Al}_{3} \mathrm{Si}_{2}\left(\mathrm{mS} 14-\mathrm{Y}_{2} \mathrm{Al}_{3} \mathrm{Si}_{2}\right)$, $\tau_{4}-\mathrm{Ho}_{2} \mathrm{AlSi}_{2}\left(\mathrm{oI} 10-\mathrm{W} 2 \mathrm{CoB}_{2}\right)$ and $\tau_{5}-\mathrm{Ho}_{6} \mathrm{Al}_{3} \mathrm{Si}\left(\mathrm{tI} 80-\mathrm{Tb}_{6} \mathrm{Al}_{3} \mathrm{Si}\right)$ have been found in the system at $500^{\circ} \mathrm{C}$, according with [16]. The $\tau_{2}$ and $\tau_{4}$ phases dissolve aluminum up to 45 at $\%$ and 25 at \% respectively.

- Different binary compounds dissolve the third element extending into the ternary system.

- By comparing the different known ternary isothermal sections, some points can be highlighted. All the sections are characterized by the presence of intermediate phases with $\mathrm{R}$ content up to 60 at $\%$ rare earth. The number of phases decreases on going from the light $(\mathrm{Pr}, \mathrm{Nd}, \mathrm{Sm})$ to the heavy rare earths (Gd, Tb, Dy, Er). Only the $\mathrm{RAl}_{2} \mathrm{Si}_{2}$ compounds form along the whole lanthanides series as point compounds; nevertheless in the previously studied Ho-Al-Si [16] and Er-Al-Si [17] isothermal sections this compound has not been founded. From La to Dyat low $\mathrm{R}$ content the three-phase equilibrium: $(\mathrm{Al}) /(\mathrm{Si}) / \mathrm{RAl}_{2} \mathrm{Si}_{2}$ occurs. Many R-Si and $\mathrm{R}-\mathrm{Al}$ compounds extend in the ternary system forming solid solutions at a constant $\mathrm{R}$-content.

\section{Conflicts of Interest}

The authors declare no conflicts of interest regarding the publication of this paper. 


\section{References}

[1] Slattery, B.E., Perry, T. and Edrisy, A. (2009) Microstructural Evolution of a Eutectic Al-Si Engine Subjected to Severe Running Conditions. Mat. Sci. and Eng. A, 512 , 76-81. https://doi.org/10.1016/j.msea.2009.01.025

[2] Miller, W.S., Zhuang, L., Bottema, J., Wittebrood, A.J., De Smet, P., Haszler, A. and Vieregge, A. (2000) Recent Development in Aluminum Alloys for the Automotive Industry. Mat. Sci. and Eng. A, 280, 37-49. https://doi.org/10.1016/S0921-5093(99)00653-X

[3] Zhu, M., Jian, Z., Yao, L., Liu, C., Yang, G. and Zhou, Y. (2011) Effect of Mischmetal Modification Treatment on the Microstructure, Tensile Properties, and Fracture Behavior of Al-7.0\%Si-0.3\%Mg Foundry Aluminum Alloys. J Mater. Sci, 46, 2685-2694. https://doi.org/10.1007/s10853-010-5135-7

[4] Cardinale, A.M., Macciò, D., Luciano, G., Canepa, E. and Traverso, P. (2016) Thermal and Corrosion Behavior of as Cast Al-Si Alloys with Rare Earth. J. Alloys Compd. https://doi.org/10.1016/j.jallcom.2016.11.066

[5] Gschdneidner Jr., K.A. (1980) The Rare Earths in Modern Science and Technology. In: McCarthy, G.J., Rhine, J.J. and Silber, H.B., Eds., Plenum, New York, 2, 13-23.

[6] Murray, J.L. and McAlister, A.J. (1984) The Al-Si (Aluminum-Silicon) System. Bull. of Alloy Phase Diagrams, 5, 74-84. https://doi.org/10.1007/BF02868729

[7] Jin, L., Kang, Y.-B., Chartrand, P. and Fuerst, C.D. (2010) Thermodynamic Evaluation and Optimization of Al-Gd, Al-Tb, Al-Dy, Al-Ho and Al-Er Systems Using a Modified Quasichemical Model for the Liquid. CALPHAD, 34, 456-466. https://doi.org/10.1016/j.calphad.2010.08.004

[8] Kim, J. and Jung, I.H. (2015) Critical Evaluation and Thermodynamic Optimization of the Si-RE Systems: Part II. Si-RE System $(\mathrm{RE}=\mathrm{Gd}, \mathrm{Tb}, \mathrm{Dy}, \mathrm{Ho}, \mathrm{Er}, \mathrm{Tm}, \mathrm{Lu}$ and Y). J. Chem. Thermodynamics, 81, 273-297. https://doi.org/10.1016/j.jct.2014.08.014

[9] Ijjaali, I., Venturini, G. and Malaman, B. (1998) X-Ray Single Crystal Refinement of the $\mathrm{Ho}_{3} \mathrm{Si}_{4}$ Structure. J. Alloys Compd, 269, L6-L8. https://doi.org/10.1016/S0925-8388(97)00626-9

[10] Murav'eva, A.O. (1971) The Systems La-Al-Si and La-Al-Sb in the Region 0-33.3 at \% La. Vestn. Lviv Univ. Ser. Khim, 12, 8-9.

[11] Li, Y., Li, Z., Liu, Y., Wang, X., Zhao, M. and Yin, F. (2014) Isothermal Section of Al-Si-Ce Ternary System at 1073 K. J. of Phase Equil. and Diffusion, 35, 276-283. https://doi.org/10.1007/s11669-014-0306-x

[12] Cardinale, A.M., Macciò, D. and Saccone, A. (2015) Phase Relationships of the R-Al-Si Systems: The Pr-Al-Si Isothermal Section at $500^{\circ}$ C. J. Therm. Anal. And Calorim, 121, 1151-1157. https://doi.org/10.1007/s10973-015-4906-4

[13] Cardinale, A.M. and Parodi, N. (n.d.) R-Al-Si Systems (R: Pr, Nd): Experimental Investigation of Phase Equilibria in the Al-Rich Corner.

[14] Markoli, B., Spaic, S. and Zupanic, F. (2001) The Constitution of Alloys in the Al-Rich Corner of the Al-Si-Sm Ternary System. Z. Metallkde, 92, 1098-1102.

[15] Zarechnyuk, O.S. and Yanson, T.I. (1982) The Eu-Al-Si System within a Range of 0 - 33.3 Atomic Parts of Europium. Akad. NaukUkr. RSR, 4, 30-31.

[16] Zhuang, Y.H., Li, J.Q. and Zeng, L.M. (1990) The Isothermal Section $\left(500^{\circ} \mathrm{C}\right)$ of the Phase Diagram of the Al-Ho-Si Ternary System. J. Less-Common Met, 157, 47-53. https://doi.org/10.1016/0022-5088(90)90405-9 
[17] Pukas, S., Lasocha, W. and Gladyshevskii, R. (2009) Phase Equilibria in the Er-Al-Si System at $873 \mathrm{~K}$. CALPHAD, 33, 23-26.

https://doi.org/10.1016/j.calphad.2008.07.017

[18] Murav'eva, A.O., Zarechnyuk, O.S. and Gladyshevskii, E.I. (1971) The systemsy-Al-Si(Ge, Sb) in the Range 0 - 33.3 at \% Y. Izv. Akad. Nauk SSSR Neorg. Mater, 1,38 .

[19] Villars, P. and Cenzual, K. (n.d.) Pearson's Crystal Data-Crystal Structure Database for Inorganic Compounds (on DVD), Release 2017/18, ASM International, Materials Park, Ohio, USA.

[20] Kraus, W. and Nolze, G. (1999) Powder Cell for Windows, Berlin.

[21] King, G. and Schwarzenbach Latcon, D. (2000) Xtal3.7 System. In: Hall, S.R., du Boilay, D.J. and Olthof-Hazekamp, R., Eds., University of Western, Australia. 